\title{
The role of honey in the
}

\section{management of wounds}

\author{
A review of the evidence on the advantages of using honey as a topical wound \\ treatment together with practical recommendations for its clinical use
}

$\mathbf{T}$ he widespread development of antibiotic-resistant bacteria has generated an increasing interest in the use of alternate therapies for the treatment of infected wounds. In 1989, an editorial in the Journal of the Royal Society of Medicine, referring to reports on the successful use of honey in wounds, stated: 'The therapeutic potential of uncontaminated, pure honey is grossly underutilized.' This paper examines how the chemical and physical properties of honey may facilitate wound healing and offers guidance on practical issues related to clinical use.

\section{Antibacterial action}

A number of laboratory studies have demonstrated the significant antibacterial activity of honey. Using concentrations of honey ranging from $1.8 \%$ to $11 \%(\mathrm{v} / \mathrm{v})$, researchers have achieved complete inhibition of the major wound-infecting species of bacteria. ${ }^{3}$ Other reports include: complete inhibition of a collection of strains of MRSA ( $1 \%-4 \% \mathrm{v} / \mathrm{v}$ honey) ${ }^{4}$ complete inhibition of 58 strains of coagulase-positive Staphylococcus aureus isolated from infected wounds $(2 \%-4 \% \mathrm{v} / \mathrm{v}$ honey) $;^{5}$ complete inhibition of 20 strains of Pseudomonas isolated from infected wounds $\left(5.5 \%-8.7 \% \mathrm{v} / \mathrm{v}\right.$ honey). ${ }^{6}$

The antibacterial activity of honey has also been shown in vivo, with reports of infected wounds dressed with honey becoming sterile in 3-6 days, 7,8 days ${ }^{9-11}$ and 7-10 days. ${ }^{12}$

Solutions of high osmolarity, such as honey, sugar and sugar pastes, inhibit microbial growth ${ }^{13}$ because the sugar molecules 'tie up' water molecules so that bacteria have insufficient water to support their growth. When used as dressings, dilution of these solutions by wound exudate reduces osmolarity to a
P.C.Molan, BSc, PhD, Director, Honey Research Unit, University of Waikato, Hamilton, New Zealand

Abscesses; Burns; Honey; Moist wound
healing;-Necrotising-fasclitis;
Ulcers; Wound infection

level that ceases to control infection, especially if wounds are infected with Staphylococcus aureus (a common osmotolerant wound pathogen). ${ }^{14,15}$ Even when diluted by exudate to a point where its osmolarity no longer inhibits bacterial growth, honey's additional antibacterial components still ensure sterility.

Honey's antibacterial activity is thought to be due primarily to the presence of hydrogen peroxide, generated by the action of an enzyme that the bees add to nectar. ${ }^{16}$ Some floral sources provide additional antibacterial components by way of plant-derived chemicals in the nectar, such as flavonoids and aromatic acids. ${ }^{17}$ This partly explains the very large variation that is seen in the antibacterial potency of honeys from different floral sources. ${ }^{18}$ However, the variation results mainly from differences in the amount of hydrogen peroxide formed in the honeys, because nectar from some floral sources contains components that break down hydrogen peroxide or destabilise the enzyme that produces it. Exposure of honey to heat and light also deactivates the enzyme that produces hydrogen per-oxide. ${ }^{18}$ Differences in the antibacterial potency are reflected in the varying sensitivity results reported for wound-infecting species of bacteria. ${ }^{18}$

The use of hydrogen peroxide as an antiseptic agent in the treatment of wounds is generally considered to give outcomes that are less than successful. However, when honey is used, the hydrogen peroxide is delivered in a very different way. Hydrogen peroxide is an effective antimicrobial agent if present at a sufficiently high concentration, ${ }^{19}$ but at 'higher concentrations-it-causes-cellular and protein damage in tissues by giving rise to oxygen radicals ${ }^{20,21}$ This limits the concentration of hydrogen peroxide that can be used as an antiseptic.

Honey effectively provides a slow-release delivery of hydrogen peroxide; the enzyme producing it becomes active only when honey is diluted ${ }^{16}$ and continues to produce it at a steady rate for at least 24 hours (unpublished work). In honey diluted with an equal volume of $\mathrm{pH} 7$ buffer, the concentration of hydrogen peroxide accumulating in one hour is typically about 1000 times less than that in the solution of hydrogen peroxide $(3 \%)$ that is commonly used as an antiseptic. Honey also has high levels of antioxi-dants, $^{22}$ which would protect wound tissues from oxygen radicals that may be produced by the hydrogen peroxide.

\section{Deodorising action}

The deodorisation of offensive odour from wounds is an expected consequence of honey's antibacterial action. The malodour is due to ammonia, amines and sulphur compounds, which are produced when infecting bacteria metabolise amino acids from proteins in the serum and necrotic tissue in a wound. The rapidity of honey's deodorising action is probably due to the provision of a rich source of glucose, which would be used by the infecting bacteria in preference to amino acids, ${ }^{23}$ resulting in the production of lactic acid instead of malodorous compounds.

\section{Debriding action}

The debriding action of honey has not yet been explained. It may be simply a 
Table I. Advantages of using honey

Wound care advantages

\begin{tabular}{l} 
It provides a protective barrier to \\
prevent cross-infection ${ }^{10,34,31,40,41,54,61}$ \\
\hline It creates an antibacterial moist healing \\
environment \\
It rapidly dears infecting bacteria ${ }^{7-12}$ \\
including antibiotic-resistant strains ${ }^{37}$ \\
\hline
\end{tabular}

It has a debriding effect and its osmotic action causes an outflow of lymph, lifting

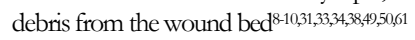

It rapidly removes malodour ${ }^{9-11,33,34,61}$

It hastens healing through stimulation of tissue regeneration ${ }^{7-10,12,26-30,33,37-41}$

It prevents scarring and

hypertrophicaton $930,33,48$

It minimises the need for skin grafting $8,9,30,61$

It is non-adherent and therefore minimises trauma and pain during dressing changes ${ }^{30,34,37,39,48,49,55}$

Its and-inflammatory action reduces oedemas. , $^{90,31-33}$

It has no adverse effect on wound tissues ${ }^{10,11,31,37,40,49}$

\section{Economic advantages}

Reduced costs of dressing materials and antibacterial agents ${ }^{12,37,52,59}$

More rapid healing $8,11,12,26,30,37,41,53$

The obviation of surgical debridement ${ }^{8-10,31}$

The obviation of skin grafting $8,9,30,33$

Ease of use allows patients to manage their own wound care at home, thus reducing nursing costs

result of the moist healing environment that is created by the honey dressing. Another possibility is that it is an enzymatic debridement process. There have been no reports of honey having any proteolytic activity, but the debridement action may be due to activation of pro-teases in wound tissues by hydrogen peroxide generated by the honey dressing. It has been reported that metalloproteases can be activated by oxidation, ${ }^{24}$ and the inhibitors of serine proteases can be deactivated by oxidation. ${ }^{25}$

\section{Anti-inflammatory action}

Histological studies using experimental wounds in animals have shown that honey has an anti-inflammatory influence even when there is no infection present, this being seen as a reduction in the number of inflammatory cells infiltrating the wound tissue. ${ }^{26-29}$ This confirms clinical observations of reduction in inflammation, ${ }^{26,30}$ oedema, ${ }^{9,10,31-33}$ and exudation, $9,10,26$ and a soothing effect $26,34,35$ when honey is applied to wounds. This anti-inflammatory influence may be associated with the antioxidant content of honey, which has been found to be of a significant level when assayed as the capacity of honey to scavenge free radicals?, Oxygen radicals are involved in various aspects of inflammation, ${ }^{25}$ and the application of antioxidants to burns has been shown to reduce inflammation. ${ }^{36}$

\section{Stimulation of tissue growth}

Honey promotes the formation of clean healthy granulation tissue $7-10,12,30,32,37-39$ and epithelialisation, $9,10,30,33,40$ as demonstrated histologically in animal studies 26-29,41 This may be due to the generation of hydrogen peroxide, low levels of which stimulate angiogenesis ${ }^{42}$ and the growth of fibroblasts ${ }^{43}$ Increased angiogenesis would provide more oxygen, which is a limiting factor for tissue regeneration.

Acidification of the wound may also be responsible: honey typically has a $\mathrm{pH}$ from 3 to 4 , and topical acidification has been shown to promote healing 44 by causing more oxygen to be released from haemoglobin. ${ }^{45}$ Also it has been suggested that the decreased turgor resulting from the application of honey may increase tissue oxygenation; 10 the reduction in hydrostatic pressure in the interstitial fluid resulting from anti-inflammatory action would allow improved circulation in the tissues.

Another theory is that the nutrient content of honey may stimulate growth - it has a wide range of amino acids, vitamins and trace elements, in addition to large quantities of readily assimilable sugars. Studies in animals ${ }^{46}$ and humans ${ }^{47}$ have shown an association between topical application of nutrients to wounds and increased growth of granulation tissue.

In addition, the high osmolarity of honey will draw fluid out from a wound bed. This outflow of lymph with its dissolved nutrients would also provide nutrition for regenerating tissue.

\section{Clinical experience}

Honey has been used to treat a number of different wound types, including surgical wounds $8,11,12,41,48-51$ most notably vulvectomy wounds, 8,11,12,41,48-51 wounds related to trauma, ${ }^{10,50,52-54}$ wounds associated with necrotising fasciitis, ${ }^{9},{ }^{33}$ pressure tlICerS ${ }^{10.38 .53^{\prime} 55.58}$ and venous and diabetic leg ulcers. ${ }^{52,59,60}$ However, it is in the management of burn wounds that the role of honey has probably received most attention. Investigations have shown honey to be more effective than other products $^{29.30 .34,61}$ in the management of partial-thickness burns. A retrospective study also has shown that honey is as effective as silver sulphadiazine in the management of burns. ${ }^{62}$

In prospective randomised controlled trials comparing honey with silver sulphadiazine-impregnated gauze in the treatment of fresh partial-thickness burns, honey was shown to produce an early subsidence of acute inflammatory changes and quicker wound healing, better control of infection, better relief of pain, less irritation of the wound, less exudation, and a lower incidence of hypertrophic scar and post-burn contracture. ${ }^{30,61}$ The advantages of using honey in the management of wounds are listed in Table 1.

\section{Guidelines for practice}

Honey varies in consistency, from liquid to solid, with the glucose content crystallised. Solid honeys may be liquified by warming and semi-solid honeys can often be liquified by stirring. Heating above $37^{\circ} \mathrm{C}$ should be avoided, as this may bum the patient and will destroy the enzyme that produces hydrogen peroxide.

The honey should be spread evenly on the dressing pad rather than directly to the wound. The amount of honey required on a wound depends on the amount of exudation; the beneficial effects of honey on wound tissues will be reduced or lost if small quantities of honey become diluted by large amounts of exudate. Wounds with deep infection require greater amounts of honey to obtain an effective level of antibacterial activity by diffusion into the wound tissues.

\section{Dressing technique}

Typically, $30 \mathrm{~mL}$ of honey is used on a $10 \mathrm{~cm} \times 10 \mathrm{~cm}$ dressing. Dressing pads impregnated with honey (such as those produced by REG International, New Zealand) (Figs $1 \& 2$ ) are the most convenient way of applying honey to surface wounds. Occlusive or absorbent secondary dressings are needed to prevent honey oozing out from the wound dressing (Fig 3). The frequency of dressing changes will also depend on how rapidly the honey is diluted by exudate. Daily dressing changes are usual, but up to three times daily may 


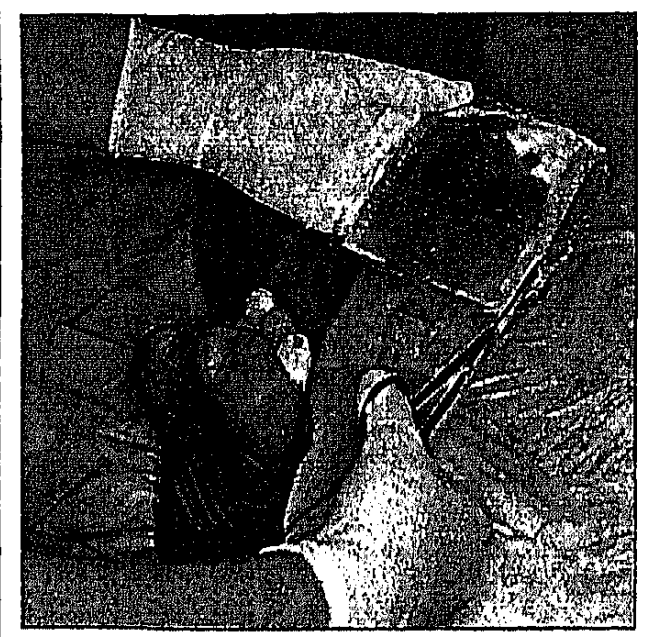

Fig 1. Dressings impregnated with honey are easy to handle

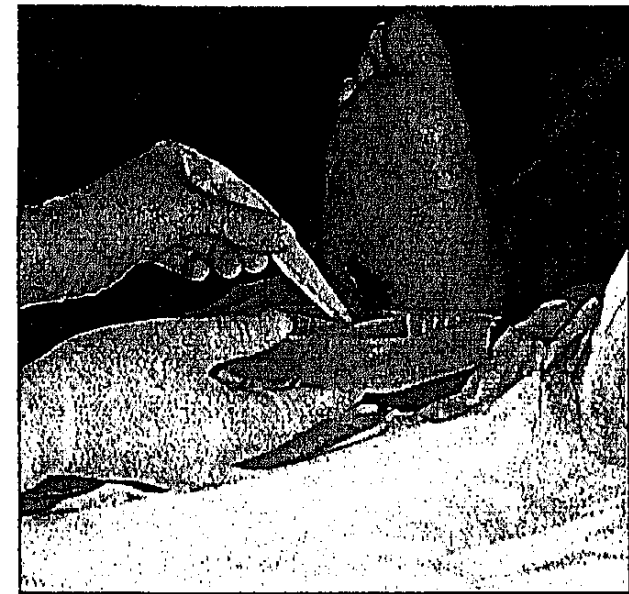

Fig 4. Honey can be used to fill a cavity wound

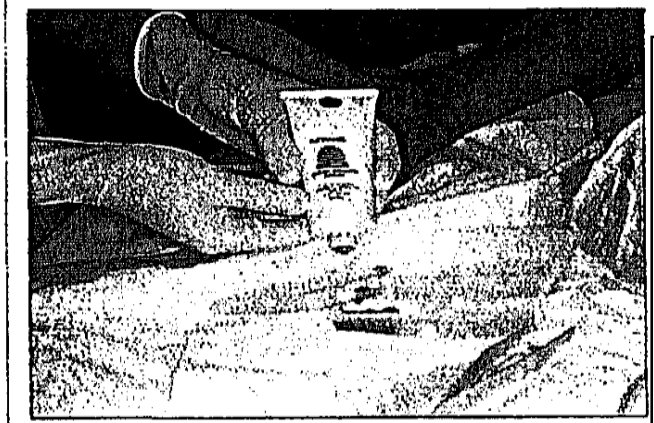

Fig 7. Tubes packed with honey are avallable for easy handling

be necessary. Exudation should be reduced by the anti-inflammatory action of honey, so the frequency of dressing changes should decline as treatment progresses. Deep wounds (Figs 4-6) or abscesses are most easily filled by using honey packed in 'squeeze-out' tubes, now available commercially (Actimel) (Fig 7).

Honey quality

Honeys from Leptospermum species (for example, manuka honey) can have a

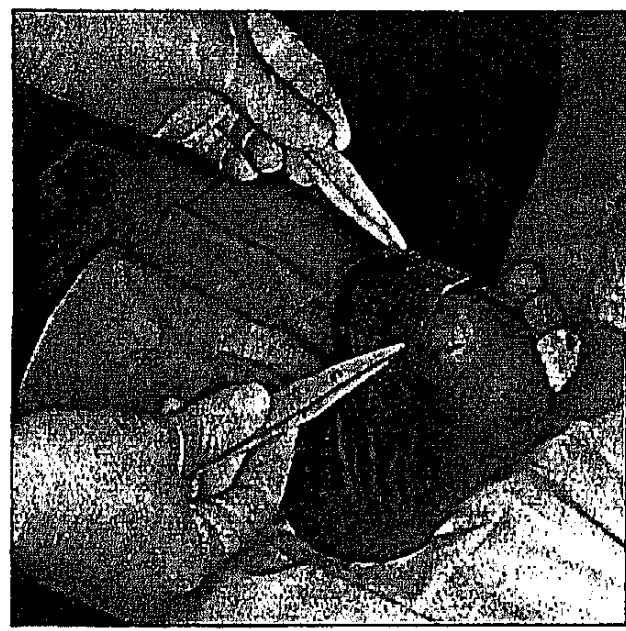

Fig 2. Honey dressing being positioned on a wound

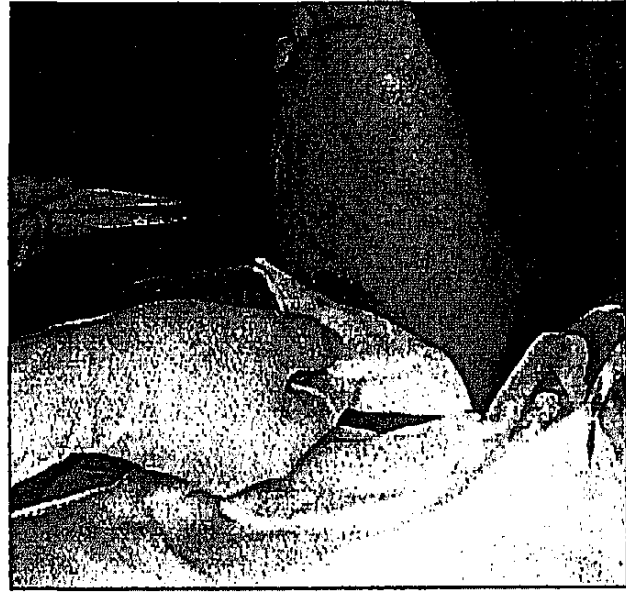

Fig 5. Filled cavity wound being covered with an absorbent dressing

uniquely high level of a herbal antibacterial component ${ }^{63}$ that is particularly effective against some of the important wound-infecting bacteria. $^{3}$ However, ail honeys vary very much in their potency. There is a high chance of the activity being little better than that of sugar if a honey is taken at random. ${ }^{63}$ There is a large variance in the level of antibacterial activity even within honeys from the same floral source.

Although ancient physicians were aware that honeys from particular sources had the best therapeutic properties, little regard is given to this in current clinical practice. Any honey to be used for infected wounds should therefore have its antibacterial activity assayed. A 'UMF' rating (equivalent to the concentration of phenol which has the same activity against Staphylococcus aureus) is being used by producers of manuka honey to show the potency of its plant-derived component.

\section{Potential risk}

There is no report of any type of infection resulting from the application of honey to wounds although there is no reference in

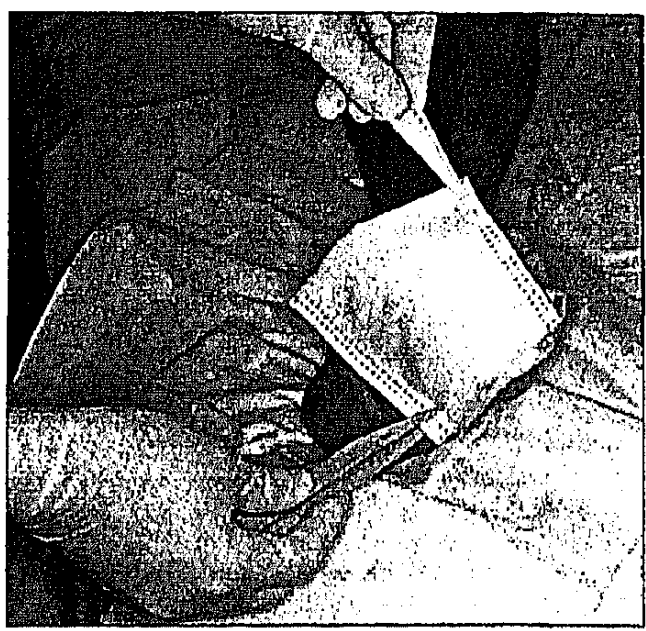

Fig 3. Occlusive or absorbent secondary dressing prevent oozing from the dressing

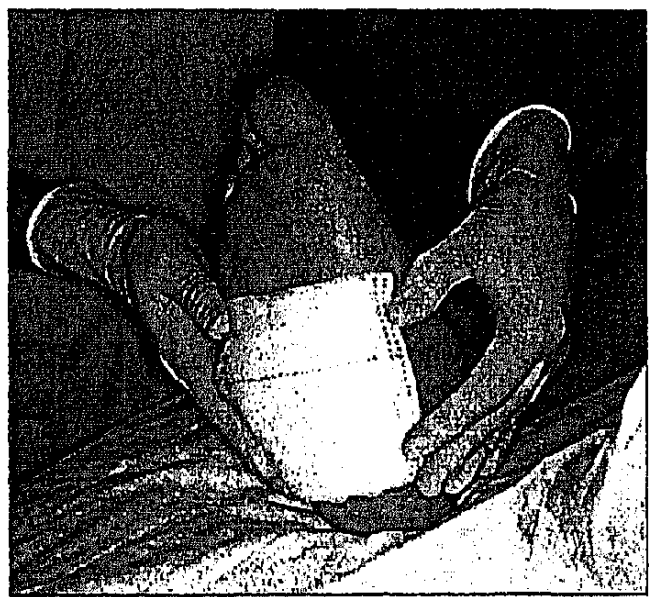

Fig 6. Secondary dressing in place before bandaging

reports of the clinical application of honey on open wounds being sterilised before use. Honey sometimes contains spores of clostridia, which poses a small risk of infection, such as wound botulism. Any risk can be overcome by the use of honey that has been treated by gamma-irradiation, which kills clostridial spores without loss of any of the honey's antibacterial activity."

\section{Conclusion}

This paper has described the chemical and physical properties of honey and has shown how these may have a positive influence on wound healing. Honey is an ideal substance to use as a wound dressing material. Its fluidity, especially when warmed, allows it to be spread and makes honey dressings easy to apply and remove..$^{37,39,55}$ The osmotic action resulting from honey's high sugar content draws out wound fluid and thus dilutes the honey that is in contact with the wound bed, minimising adhesion or damage to the granulating surface of the wounc $1^{30-44,49}$ when the dressing is removed. ${ }^{34}$ The high solubility of honey in water allows residual 
honey to be washed away by bathing ${ }^{54}$

Although the clinical experiences detailed in this paper show positive results, more quality randomised controlled trials are needed to provide evidence to encourage the use of honey in wound care.

\section{REFERENCES}

I. Greenwood, D. Sixty years on: antimicrobial drug resistance comes of age. Lancet 1995; 346: (Suppl I), s I,

2. Zumla, A., Lulat, A. Honey; a remedy rediscovered. JR Soc Med 1989; 82: 384-385

3. Willix, D.J., Molan, P.C., Harfoot, C.J. A comparison of the sensitivity of wound-infecting species of bacteria to the antibacterial activity of manuka honey and other honey.] Appl Bacteriol 1992: 73: 388-394.

4. Molan, P.. Brett. M. Honey has potential as a dressing for wounds infected with MRSA. The Second Australian Wound Management Association Conference: 1998

March 18-21; Brisbane, Australia.

5. Cooper, R.A., Molan, P.C., Harding, K.G. The

effectiveness of the antibacterial activity of honey against strains of Staphylococcus aureus isolated from infected wounds.) R Soc Med 1999; 1999; 92: 283-285.

6. Cooper, RA, Molan, P.C. The use of honey as an antiseptic in managing Pseudomonas infection.) Wound Care 1999; 8: 4, 161-164.

7. Branikl, F.J. Surgery in Western Kenya. Ann R Con Surg Eng! 1981; 63: 348-352.

8. Cavanagh, D., Beazley, J., Ostapowica F. Radical

operation for carcinoma of the vulva: a new approach to wound healing.) Obstet Gynaecol Commonw 1970; 77 : I 1, 1037.1140.

9, Efem, S.E.E. Recent advances in the management of Fournier's gangrene; preliminary observations. Surgery 1993; 113: 2. 200-204,

10. Efem S.E,E, Clinical observations on the wound healing properties of honey. Sr) Surg 1988; 75: 679.681.

11. Phuapradit, W., Saropala, N. Topical application of honey In treatment of abdominal wound disruption. Austr NZ J Obstet Gynaecol 1992; 32: 4, 381-384. 12. Amors, P.J. The use of honey in the treatment of infected wounds. Trop Doct 1980; 10: 91.

13. Chirfe, J., Scarmato, G., Herszage, L. Scientific basis for use of granulated sugar in treatment of Infected wounds. Lancet 1982; I: (March 6), 560-561.

14. Chirife, J., Herszage, L. Joseph, A. et at In vitro study of bacterial growth inhibition in concentrated sugar solutions: microbiological basis for the use of sugar in treating infected wounds. Antimicrobial Agents \& Chemother 1983; 23: 5, 766-773.

I5. Herszage, L, Montenegro, J.R., Joseph, A.L Tratamiento de las heridas supur-adas con azcecar granulado comercial. Bol Trab Soc Argent Or 1980; 41: 21-22, 315-330

16. White, J.W., Subers, M.H., Schepart, A.I. The identification of inhibine, the antibacterial factor in honey, as hydrogen peroxide and Its origin In a honey glucose-oxidase system. Blochim alophys Acta 1963; 73 : $57-70$.

17. Molan P.C. The antibacterial activity of honey, I: The nature of the antibacterial activity. Bee World 1992; 73: 1, 5-28.

18. Molan, P.C. The antibacterial activity of honey. 2: Variation in the potency of the antibacterial activity. Bee World 1992; 73: 2, 59-76.

19. Roth, L.A., Kwan, S., Spoms, P. Use of a disc-assay system to detect oxytetracycline residues in honey. J Food Prot 1986; 49: 6, 436-441.

20. Cochrane, C.G. Cellular injury by oxidants. Am JMed 1991; 91: (Suppl 3c), 235.305.

21. Simon, R.H., Scoggin, C.H.. Patterson, D. Hydrogen peroxide causes the fatal injury to human fibroblasts exposed to oxygen radicals. J Biol Chem 1981; 256: 14 , 7181-7186.

22. Frankel, 5., Robinson, G.E., Berenbaum, M.R. Antioxidant capacity and correlated characteristics of 14 unifioral honeys. J Apic Res 1998; 37: I, 27-31.

23. Nychas, G.J., Dillon, V.M., Board, R.G. Glucose, the key substrate in the microbiological changes in meat and certain meat products. Brotechnol App/ Biochem 1988; 10: 203-231. 24. Van Wart, H.E.. Birkedal-Hansen, H. The cystein

\section{KEY ISSUES FOR PRACTICE}

- The use of honey dressings may have a beneficial effect in wound management and can be cost-effective

- Solid honeys may be liquified by stirring or warming but honey should not be heated above $37^{\circ} \mathrm{C}$

- The honey should be spread evenly and applied to the dressing pad rather than directly the wound

- Deep wounds can be filled with honey from a 'squeeze-out' tube

- The amount of honey required depends on the amount of exudate; wounds with deep infection require greater amounts of honey

- Dressing pads pre-impregnated with honey are the most convenient method of applying honey to wounds

- Frequency of dressing change depends on quantity of exudate

switch: a principle of regulation of metalloproteinase activity with potential applicability to the entire matrix metalloproteinase gene family. Proc Nat Acad Sri USA 1990;87: 14.5578-5582

25. Floh, L. Beckmann, R., Giertz, H. et al.

Oxygen-centred free radicals as mediators of inflammation. In: Sies, H. (ed). Oxidative Stress. London, Orlando: Academic Press, 1985.

26. Burlando, F. Sull'azione terapeutica del miele nelle ustioni. Minerva Dermatol 1978; 113: 699-706.

27. Gupta, S.K., Singh, H., Varshney, A.G. et al. Therapeutic efficacy of honey in infected wounds in buffaloes. Indian J Anim Sri 1992; 62: 6, 521-523. 28, Kumar, A., Sharma, V.K., Singh, H.P. et al. Efficacy of some indigenous drugs in tissue repair in buffaloes. Indian Vet) 1993; 70: I, 42-44.

29. Postures, T.J., Bosch, M.M.C., Dutrieux, R. et al. Speeding up the healing of burns with honey. An experimental study with histological assessment of wound biopsies. In: Mizrahl, A., tensity, Y. (eds). Bee Products: Properties, applications and apitherapy. New York, NY: Plenum Press, 1997

30. Subrahmanyam, M. A prospective randomised clinical and histological study of superficial burn wound healing with honey and silver sulfadiazine. Bums 1998; 24: 2 , 157-161.

31. Subrahmanyam, M. Honey dressing versus boiled potato peel in the treatment of burns: a prospective randomized study. Bums 1996; 22: 6, 491-493.

32. Dumrongiert, E. A follow-up study of chronic wound healing dressing with pure natural honey. ) Nat Res Counc Than 1983; 15: 2, 39-66.

33. Hejase,11.J., Simonin, Blhrle, R., Coogan. C.L Genital Fournier's gangrene: experience with 38 patients Urology 1996; 47: 5. 734-739.

34. Subrahmanyam, M. Honey impregnated gauze versus polyurethane film (OpSite) in the treatment of burns: a prospective randomised study. Br) Piast Surg 1993; 46: 4 , 322.323.

35. Keast-Butler J. Honey for necrotic malignant breast ulcers. Lancet 1980; $\quad$ (October II ), 809.

36. Tanaka, H., Hanumadass, M., Matsuda. H. et al. Hemodynamic effects of delayed initiation of antioxidant therapy (beginning two hours after burn) in extensive third-degree burns.] Burn Care Rehabil 1995; 16: 6, 610-615

37. Farouk, A., Hassan, T., Kashif, H. et at Studies on Sudanese bee honey: laboratory and clinical evaluation. int J Crude Drug Res 1988; 26: 3, 161-168.

38. Hutton. D.J. Treatment of pressure sores. Nurs Times 1966; 62: 46, 1533-1534.

Wadi. M., Al-Amin, H., Farouq, A. et al. Sudanese bee honey in ;he treatment of suppurating wounds. Arab Medico 1987; 3: 16-18.

39. Subrahmanyam, M. Honey-impregnated gauze versus amniotic membrane in the treatment of burns. Bums 1994; 20:4, 331-333

40. Bergman, A., Yana!, J., Weiss, J. et al. Acceleration of wound healing by topical application of honey: an anima model. Am J Surg 1983; 145: 374-376.

41. Tur, E., Bolton, L, Constantine, B.E. Topical hydrogen peroxide treatment of ischemic ulcers in the guinea pig: blood recruitment in multiple skin sites. J Am Acad Dermatoi 1995; 33:2 (Part I), 217-221.

42. Schmidt, R.J., Chung, LY., Andrews, A.M. et al. Hydrogen peroxide is a murine (L929) fibroblast cell proliferant at micro- to nanomolar concentrations. In Harding, K.G., Cherry. G., Dealey, C.. Turner, T.D. (eds). Proceedings of the 2nd European Conference on Advances in Wound Management. London: Macmillan Magazines, 1993.

43. Kaufman, T., Eichenlaub, E.H., Angel, M.F. et al. Topical acidification promotes healing of experimental deep partial thickness skin burns; a randomised double-blind preliminary study. Bums 1985; 12 : 84-90.

44. Leveen, N.H., Falk, G., Borek, B. et al. Chemical acidification of wounds: an adjuvant to healing and the unfavourable action of alkalinity and ammonia, Ann Surg 1973; 178: 6, 745-753.

45. Kaufman, T., Levin, M., Hurwitz, D.J. The effect of topical hyperalimentadon on wound healing rate and granulation tissue formation of experimental deep second-degree burns in guinea-pigs. Bums 1984; 10: 4, 252-256

46. Viljanto, J., Raekallio, J. Local hyperallmentation of open wounds. Br) Surg 1976; 63: 3, 427-430.

47. Mclnemey, R.J.F. Honey: a remedy rediscovered.

J R Soc Med 1990; 83: 127.

48. Bulman, M.W. Honey as a surgical dressing. Middlesex Hosp / 1955; 55: 188-189.

49. Ndaylsaba, G., Bazira, L, Habonimana, E. et at

Clinical and bacteriological results in wounds treated with honey. J Orthop Surg 1993; 7: 2, 202-204. 50. Dany-Mazeau, M., Pautard, G. L'utilisadon du miel dans le processus de cicatrisation: de la ruche a PhOpital. Krankenpfl Soins Infirm 1991; 84: 3, 63-69. 52. Wood, B., Rademaker, M., Molan, P.C. Manuka honey, a low cost leg ulcer dressing. N Z Med J 1997; 110: 107.

53. Hamdy, M.H., El-Banby, MA, Khakifa ICl. et al. The antimicrobial effect of honey in the management of septic wounds. In: Proceedings of the Fourth International Conference on Apiculture in Tropical Climates. London: International Bee Research Association, 1989.

54. Green, AE Wound healing properties of honey. $\mathrm{Br} J$ Surg 1988; 75: 12, 1278

55. Blomfleld, R. Honey for decubitus ulcers. J Am Med Assoc 1973; 224: 6, 905

56. Dany-Mazeau, M.P.G. Honig auf die Wunde.

Krankenpflege 1992; 46: 1, 6-10.

57. SomeHield, S.D. Honey and healing.) R Soc Med

1991: 84: 3, 179

58. Weheida, S.M.. Nagubib, H.H. El-Banna, H.M. et at Comparing the effects of two dressing techniques on healing of low grade pressure ulcers. J Med Res Inst Alexandria Univ 1991; 12: 2.259-278.

59. Harris, S. Honey for the treatment of superficial wounds: a case report and review. Primary intention 1994; $2: 4,18-23$

60. Tovey, F.I. Honey and healing. j R Sot Med 1991: 84 7,447

61. Subrahmanyam, M. Topical application of honey in treatment of burns. Br. 1 Surg 1991; 78: 4, 497-498. 62. Adesunkanmi, K., Oyelami, O.A. The pattern and outcome of burn injuries at Wesley Guild Hospital, llesha, Nigeria: a review of 156 cases.) Trop Med Hyg 1994; 97: 2, 108-112

63. Allen, K.L, Molan, P.C., Reid, G.M. A survey of the antibacterial activity of some New Zealand honeys. $J$ Phorm Pharmacol 1991; 43: 12, 817-822.

64. Molan, P.C., Allen, K.L The effect of

gamma-irradiation on the antibacterial activity of honey. JPhorm Pharmacol 1996; 48: 1206-1209. 